\title{
Membangun Personal Branding melalui YouTube
}

\author{
${ }^{1}$ Widya Nur Bhakti Pertiwi, ${ }^{2}$ Arum Wahyuni Purbohastuti, ${ }^{3}$ Enok Nurhayati \\ 1,2,3 Fakultas Ekonomi dan Bisnis Universitas Sultan Ageng Tirtayasa \\ Email: ${ }^{1}$ widya.nbp@ untirta.ac.id ${ }^{*}$ \\ *corresponding author
}

Keywords:

Marketing

Communication,

Personal Branding

Marketing Strategy
This research generally aims to develop personal branding research with social media. The previous research took Instagram, Facebook, or Twitter media, but this research focuses on personal branding on YouTube. This research method is a qualitative and descriptive method by observing Raditya Dika YouTube Channel and interviews with several Subribers Raditya Dika. The study describes the situations or events and does not seek links, hypotheses, or make predictions. In this research, the indicators of personal branding are authenticity, integrity, consistency, specialization, authority, distinctiveness, relevance, visibility, persistence, goodwill, and performance. The subject of this research is Raditya Dika's YouTube channel, and the object of this research is a personal brand Raditya Dika through a personal YouTube channel. The results show that Raditya Dika can form, even enhance a positive image by establishing personal branding through YouTube.

\section{PENDAHULUAN}

Kasali (2013) membagi branding ke dalam tiga kategori, yaitu personal branding, corporate branding, dan product branding (Wardi, 2014:101). Individu sebagai personal dapat menggunakan branding, melalui personal branding. Personal branding adalah proses membawa skill, kepribadian, dan karakter unik seseorang, untuk kemudian membungkusnya menjadi sebuah identitas yang memiliki kekuatan lebih (Agustinna, et.al., 2017:1028). Personal branding telah dibangun atau dibentuk seseorang melalui profesi yang digeluti seseorang, seperti artis, pengacara, dokter, dan profesi sebagai influencer. Profesi sebagai influencer perlu membangun personal branding, guna mendukung profesinya.

Personal branding melalui sosial media Instagram membawa banyak hal positif dalam kehidupan seorang selebgram. Penelitian oleh Yunitasari dan Japarianto (2013), menyebutkan bahwa dalam membangun personal branding ada faktor yang menyebabkan branding dikenal, diantaranya adalah aktor unik, eksistensi, dan juga spesialisasi. Dalam Instagram, unik, eksistensi, dan spesialisasi menjadi hal yang penting. Sisi positif dari nilai unik, eksistensi dan spesialisasi, dapat membantu selebgram membangun kerjasama dengan pihak sponsor atau brand. Koneksi dan kerjasama dengan sponsor atau brand tercipta karena adanya reputasi baik melalui media sosial (Agustinna, dkk, 2017).

Pembentukan personal branding harus didasari kenyataan dalam kehidupan dengan berbagai aktivitas positif yang memperkuat pembentukan personal branding tersebut (Soraya, 2017). Penelitian Franzia (2018), mengatakan bahwa cara untuk meningkatkan pembentukan personal branding melalui menampilkan foto profil yang menunjukkan minat, memiliki kesadaran akan citra diri individu, menampilkan secara konsisten dan berulang foto, serta menggunakan media sosial sesuai dengan fungsi dan tujuannya.

Pada era digital penggunaan media digital sangat tinggi. Sosial media menjadi salah satu media komunikasi yang banyak diminati, seperti YouTube, Facebook, Instagram, dan Twitter. Data menjelaskan bahwa Youtube adalah platform media sosial terbesar penyedia video streaming di dunia, bahka Lembaga riset pasar Statista memprediksi bahwa pengguna Youtube akan mencapai 1,8 Miliar pada tahun 2021 (Permana, 2018).

Youtube menjadi salah satu platform favorit di Indonesia. Komposisi penduduk Indonesia yang sebagian besar adalah milenial (usia 20-34 tahun) menjadikan tingginya akses terhadap 
YouTube. Google bersama Kantar TNS mewakili YouTube memaparkan hasil riset bahwa 92\% pengguna internet di Indonesia menyatakan Youtube sebagai tujuan pertama ketika mencari konten video. Selain itu, dari 1500 responden yang terlibat dalam riset Google, 53\% responden menyatakan bahwa akses terhadap Youtube dilakukan setiap hari, dan menghabiskan waktu 59 menit setiap hari menonton Youtube.

Tabel 1. Daftar YouTuber Indonesia dengan Jumlah Subcriber Terbanyak

\begin{tabular}{llll}
\hline No. & \multicolumn{1}{c}{ YouTuber } & $\begin{array}{c}\text { Jumlah } \\
\text { Subscriber }\end{array}$ & Tahun Pertama Memiliki Youtube \\
\hline 1 & Atta Halilintar & 24,6 juta & 2017 \\
\hline 2 & Ria Ricis & 21,4 juta & 2016 \\
\hline 3 & Gen Halilintar & 16,6 juta & 2015 \\
\hline 4 & Rans Entertainment & 16,7 juta & 2016 \\
\hline 5 & Saai Halilintar & 12,5 juta & 2016 \\
\hline 6 & Raditya Dika & $\mathbf{8 , 9 1}$ juta & 2012 \\
\hline 7 & Baim Paula & 15,1 juta & 2019 \\
\hline 8 & Miaw Aug & 10,9 juta & 2014 \\
\hline 9 & Arif Muhammad & 2,45 juta & 2015 \\
\hline 10 & Jess No Limit & $\mathbf{1 6 , 6}$ juta &
\end{tabular}

Salah satu influencer yang berkiprah di Youtube dan mendapatkan peminat banyak adalah Raditya Dika (Radit). Radit adalah creator Indonesia yang pertama kali mendapatkan Gold Play Button, dan juga memiliki subscriber tertinggi per Mei 2018, yaitu 3,6 juta, dan pada April 2019 mencapai 6,4 subcriber (www.youtube.com), dan merupakan Youtuber yang paling lama berkancah di Youtube.

Jika melihat kepada kegiatan yang dilakukan oleh Raditya Dika, semua yang dilakukan tidak terlepas dari personal branding yang dimilikinya, sehingga berdasarkan kepada pemikiran tersebut maka tujuan dari penelitian ini adalah untuk melihat bagaimana membangun personal branding melalui youtube.

\section{KERANGKA TEORITIS}

\section{Personal Branding}

Menurut David A.Aaker "brand adalah nama dan simbol yang bersifat membedakan (seperti sebuah logo, cap, atau kemasan) dengan maksud mendefinisikan barang atau jasa dari seorang penjual atau sebuah kelompok penjual tertentu (Soraya, 2017). Menurut Haroen (2014), branding adalah aktivitas yang dilakukan untuk membangun persepsi orang lain terhadap individu mengenai siapa individu tersebut (Soraya, 2017), sehingga dapat disimpulkan bahwa branding merupakan upaya untuk membuat sesuatu produk atau jasa atau personal berbeda dengan yang lainnya.

Personal branding merupakan proses dimana manusia dipandang dan dinilai sebagai sebuah merek oleh target pasar. Personal branding juga merupakan seni menarik lebih banyak klien, dan dengan aktif membentuk persepsi publik.

Personal branding menurut Montoya adalah sebuah produk, baik barang atau jasa, agar brand itu terus menancap dihati masyarakat dengan segala atribut dan perbedaan yang dimiliki ibutuhkan upaya yang disebut branding (Haroen, 2014:13). Personal branding merupakan proses menciptakan atau membentuk pandangan (persepsi) masyarakat terhadap karakter seseorang.

Personal branding berdasarkan pada Peter Montoya dan Rampersad (Septriadi, 2012) adalah yang berkelanjutan, otentik, konsisten, dan mudah diingat terkait dengan beberapa kriteria penting yang telah disimpulkan. Beberapa kriteria personal branding menurut Peter Montoya dan Rampersad yang dimiliki diantaranya authentic, integrity, consistency, specialization, authority, distinctiveness, relevant, visibility, performance, goodwill, persistence.

- Authentic (Keaslian), yaitu menjadi diri sendiri, tidak berusaha menjadi orang lain untuk menunjukkan citra tertentu dimata masyarakat. 
- Integrity (integritas), adalah dimana seseorang harus berpegang pada pedoman moral dan juga perilaku yang sudah ditetapkan oleh ambisi pribadi.

- Consistency (konsisten), merupakan tindakan yang dilakukan seseorang secara relevan dan terusmenerus.

- Specialization (spesialisasi), yaitu fokus pada satu bidang tertentu.

- Authority (otoritas), adalah dimana seseorang terlihat sebagai seorang ahli yang dikenal dalam bidang tertentu, dengan bakat yang luar biasa, sangat berpengalaman, dan dipandang sebagai seorang pemimpin yang efektif.

- Distinctiveness (unik), yaitu berbeda, atau memiliki ciri khas yang tidak dimiliki orang lain, sehingga memiliki nilai tambah.

- Relevant (relevan), yaitu seseorang harus terkait dengan sesuatu yang dianggap penting oleh audien.

- Visibility (visibilitas), merupakan pengulangan terus-menerus dan pemaparan brand dalam jangka panjang, sehingga terlihat dengan jelas.

- Persistence (persistensi), merupakan kegigihan seseorang dalam melakukan sesuatu secara terusmenerus.

- Goodwill adalah ketika seseorang sudah diasosiasikan secara positif oleh orang lain.

- Performance (kinerja), merupakan elemen penting setelah brand tersebut atau seseorang tersebut telah dikenal, yang didapatkan dari bagaimana kinerja seseorang, setelah menjadi terkenal.

\section{Media Sosial}

Media sosial adalah media online, dimana para pengguna (user) melalui aplikasi berbasis internet, dapat berbagi, berpartisipasi, dan menciptakan konten berupa blog, wiki, forum, jejaring sosial, dan ruang virtual yang didukung oleh teknologi multimedia yang semakin canggih (Tim Pusat Humas Kementerian Perdagangan RI, 2014:25).

Menurut Juju dan Sulianta (2010), media sosial merupakan kombinasi antara ruang lingkup elemen dunia maya, dalam produk-produk layanan online seperti blog, forum diskusi, chat room, email, website, dan juga kekuatan komunitas yang dibangun pada jejaring sosial. Apa yang dikomunikasikan di media sosial memberikan efek "power" tersendiri, karena akses pembangunannya berupa teknologi dan juga berbagai media interaksi yang dikomunikasikan dengan teks, gambar, foto, audio, dan video (Agustinna, et. al., 2017:1031).

Definisi lain menurut Kaplan dan Haenlein media sosial adalah sebuah kelompok aplikasi berbasis internet yang dibangun diatas dasar ideologi dan teknologi Web 2.0, sehingga memungkinkan penciptaan dan pertukaran user-generated content (Abugaza, 2013:17; Nastiti, 2016). Jadi yang dimaksud dengan media sosial adalah aplikasi yang menggabungkan elemen- elemen yang terdapat di dunia maya atas dasar ideology dan teknologi, yang memungkinkan interaksi sosial para penggunanya.

\section{Youtube}

Youtube. Media sosial Youtube mengedepankan layanan bertukar video antar pengguna. Awalnya, Youtube dipandang sebagai wadah untuk "menyiarkan diri", serta menampung wacana budaya partisipasi dan kemunculan generasi konsumen baru yang lebih kreatif dan berdaya (Burgess \& Green, 2009:4). Namun, seiring perkembangannya, Youtube menjelma menjadi sebuah media besar yang konten-konten videonya tidak hanya ditonton oleh anggotanya saja, tetapi juga oleh banyak orang di seluruh penjuru dunia.

\section{METODE PENELITIAN}

Metode yang digunakan dalam penelitian ini adalah metode penelitian kualitatif deskriptif. Penelitian ini memaparkan situasi atau peristiwa dan tidak mencari hubungan serta tidak menguji hipotesis atau membuat prediksi (Rakhmat, 2009:24). Penelitian deskriptif kualitatif memusatkan diri pada suatu unit tertentu dari berbagai fenomena. Dengan demikian memungkinkan penelitian dapat dilakukan secara mendalam dan kedalaman data menjadi pertimbangan dalam penelitian (Bungin, 2008:68). Metode kualitatif adalah pendekatan yang berusaha menangkap aspek-aspek dunia sosial yang sulit diukur dengan angka-angka (Neuman, 2003:146). Adapun yang menjadi subyek dalam 
penelitian ini adalah channel YouTube Raditya Dika, dengan obyek penelitian ini adalah personal branding Raditya Dika melalui channel YouTube pribadi. Unit analisis pada penelitian ini, sebagai berikut:

\begin{tabular}{lll} 
& & Tabel 2 Unit Analisis \\
\hline $\mathrm{N}$ & \multicolumn{1}{c}{ Jenis } & \multicolumn{1}{c}{ Unit Analisis } \\
$\mathrm{O}$ & & \\
\hline 1 & Personal Branding & Karakteristik personal branding: \\
& & Authenticity, Integrity, Consistency, \\
& & Specialization, Authority, \\
& & Distinctiveness, Relevant, Visibility, \\
& & Persistence, Goodwill, Performance \\
\hline 2 & YouTube & Fitur Youtube: \\
& & Video, Playlist, Komunitas, Channel, \\
& & Tentang
\end{tabular}

Sumber: Data yang diolah Peneliti tahun 2020

\section{HASIL PENELITIAN DAN DISKUSI}

\section{Deskripsi Youtube Raditya Dika}

Raditya Dika, lahir di Jakarta 28 Desember 1984. Raditya Dika merilis novel pertamanya bertajuk Kambing Jantan: Sebuah Catatan Harian Pelajar Bodoh saat usianya 21 tahun. Selang setahun, ia merilis novel kedua bertajuk Cinta Brontosaurus, disusul dengan Radikus Makankakus: Bukan Binatang Biasa (2007), Babi Ngesot: Datang tak Diundang Pulang tak Berkutang (2008), Marmut Merah Jambu (2010), dan Manusia Setengah Salmon (2011).

Seluruh novel-novel Raditya Dika berhasil masuk ke dalam deretan novel-novel best seller, sehingga menimbulkan ketertarikan produser untuk mengangkat novel Kambing Jantan menjadi film layar lebar, dan rilis pada tahun 2009. Raditya semakin melebarkan sayapnya dengan berpartisipasi dalam stand up comedy, dan dinobatkan sebagai salah satu komika berpengaruh di Indonesia, serta dipercaya sebagai juri Stand Up Comedy Indonesia di Kompas TV dan Stand Up Comedy Academy di Indosiar. Kiprah Raditya Dika dalam dunia YouTube sudah dimulai sejak tahun 2012, dan pada saat itu YouTube belum terlalu diminati.

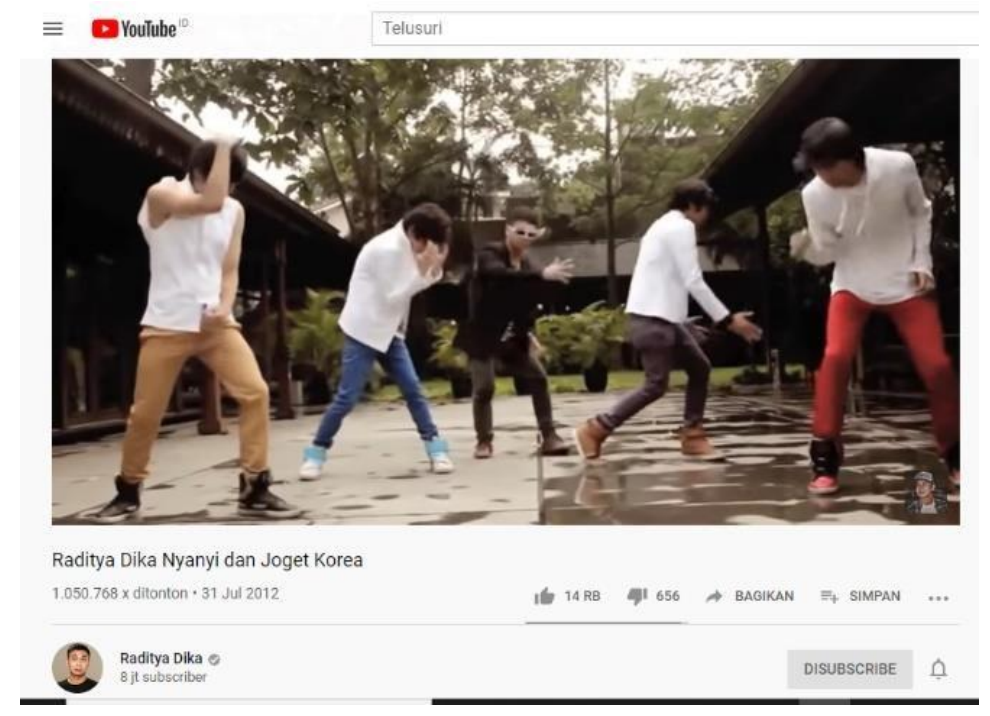

Gambar 1. Video Pertama yang Diunggah di akun YouTube Raditya Dika pada 31 Juli 2012 Source: youtube.com/user/radityadika [diakses, 2 Oktober 2019]

Video dengan judul "Raditya Dika Nyanyi dan Joget Korea" berhasil menembus 1 juta lebih viewers. Namun, pencapaian tertinggi Raditya sendiri dalam YouTube adalah melalui sitkom yang berjudul "Malam Minggu Miko". Selanjutnya, video dengan judul "Stand Up Comedy Raditya Dika 
(SUCRD)" merupakan video dengan jumlah viewers terbanyak diantara video milik Raditya Dika, dengan menembus 17 juta lebih viewers.

\section{Membangun Personal Branding melalui YouTube}

Peter Montoya (2005), dan Rampersad (2006, 2007) mengemukakan, kriteria yang harus dipenuhi dalam melakukan kegiatan personal branding agar efektif, diantaranya:

1. Authenticity (Keaslian)

Authenticity atau keaslian adalah refleksi dari karakter yang sesungguhnya. Personal branding harus dibangun dari kepribadian sejati dan harus mencerminkan karakter, perilaku, nilai serta visi seseorang. Personal branding harus diselaraskan dengan ambisi pribadi (Rampersad, 2008:19). Personal branding yang dibangun oleh seseorang haruslah sesuai dengan perilaku sehari-hari, maupun kepribadiannya. Personal branding yang tidak sesuai dengan prilaku maupun kepribadian akan menjadi brand yang tidak jujur dan tidak akan menjadi wakil dari pribadi seseorang tersebut. Raditya Dika dalam channel YouTube pribadinya melakukan kegiatan yang mewakili perilaku dan kepribadiannya. Raditya Dika tidak berusaha membentuk citra untuk menjadi seperti orang lain, dan citra yang dipersepsikan dalam channel Youtube miliknya adalah Raditya Dika sebagaimana adanya dalam kehidupan sehari-hari.

Raditya Dika memiliki cita-cita menjadi seorang penulis, yaitu penulis dengan genre komedi, dan mulai menulis melalui blog pribadinya. Raditya Dika juga mengungkapkan bahwa gaya menulis komedinya ia pelajari dari membaca buku-buku Jimmy Carter, Schopenhauer, dan juga dari menonton acara Jerry Seinfield, dan Ellen DeGeneres. Melalui channel YouTube pribadinya hal tersebut sangat terlihat, mulai dari kegiatan sehari-hari, sampai konten-konten kreatif yang ia buat seluruhnya bergaya komedi.

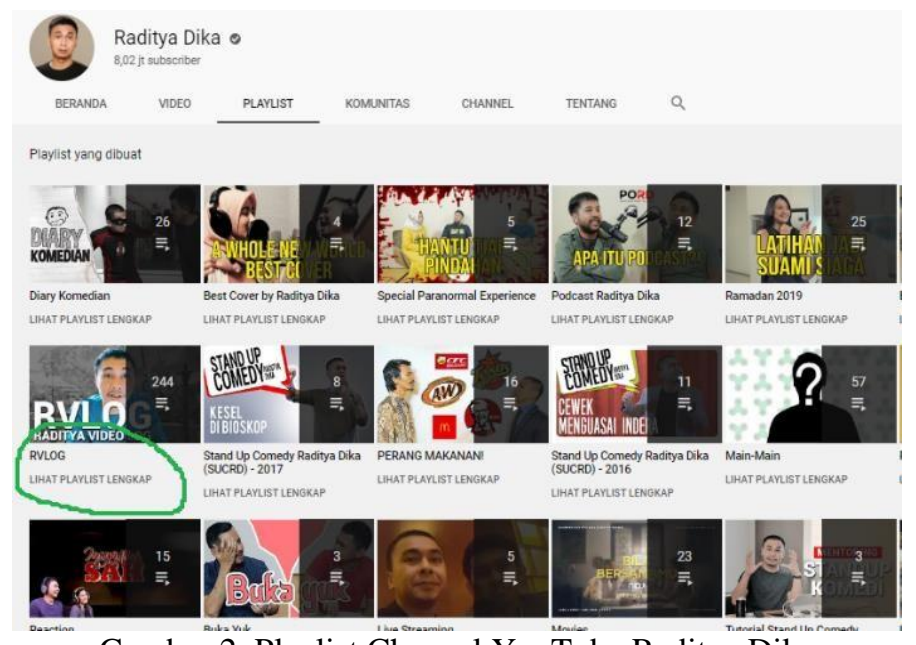

Gambar 2. Playlist Channel YouTube Raditya Dika

Source: youtube.com/user/radityadika [diakses, 2 Oktober 2019]

Raditya Dika memiliki playlist yang diberi nama RVLOG, yang berisikan kumpulankumpulan video keseharian Raditya Dika yang dikemas secara natural. Video-video tersebut berisi tentang bagaimana Raditya Dika dalam menjalani kesibukannya sehari-hari sebagai penulis, sutradara, stand up comedian maupun kesehariannya bersama keluarga dan kucing-kucingnya. Video yang ratarata berdurasi 10-15 menit tersebut banyak menunjukkan sisi personal Raditya Dika yang humoris. Video-video tersebut menunjukkan bahwa karakter dan kepribadian Raditya Dika sesungguhnya memang humoris.

\section{Integrity (integritas)}

Integritas adalah dimana seseorang harus berpegang pada pedoman moral dan juga perilaku yang sudah ditetapkan oleh ambisi pribadi. Raditya Dika dalam channel YouTubenya sebagai komedian berpegang teguh pada pedoman moral, dimana dalam-dalam videonya Raditya Dika tidak menyinggung SARA. Adapun roasting (meledek seseorang) yang ditampilkan dalam account Youtube Raditya Dika, sudah mendapat persetujuan dari individu yang bersangkutan. Hal ini menjadikan track record Youtube Raditya Dika baik dan memiliki integritas. 


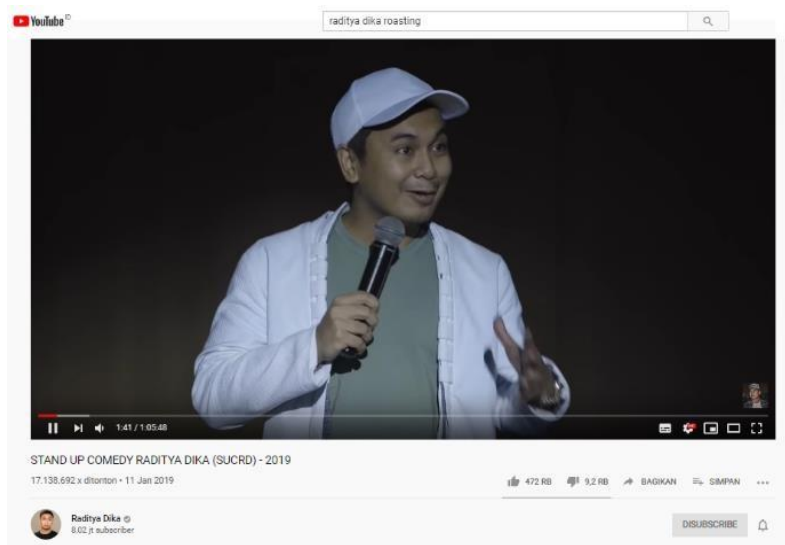

Gambar 3. Video Stand Up Comedy Raditya Dika pada Tahun 2019

Source: youtube.com/user/radityadika [diakses, 2 Oktober 2019]

\section{Consistency (Konsisten)}

Sejak mengunggah video pertamanya, Raditya Dika konsisten membuat konten-konten menarik yang bergaya komedi. Hal ini dilihat pada playlist channel Youtube Raditya Dika, dimana video-videonya berisikan tentang konten-konten komedi. Dapat dikatakan Raditya Dika konsisten dalam mempertahankan brand dirinya, karena melakukan relevan secara terus-menerus dan terlihat dalam gambar 4 berikut:

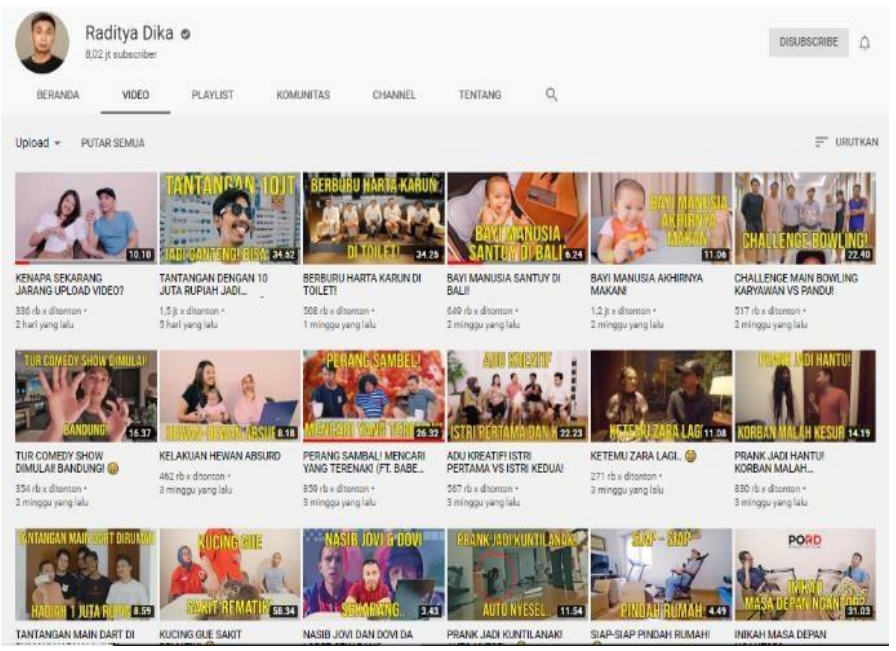

Gambar 4. Daftar Video di Channel YouTube Raditya Dika Source: youtube.com/user/radityadika [diakses, 2 Oktober 2019]

\section{Specialization (Spesialisasi)}

Spesialisasi adalah adanya fokus pada satu bidang tertentu. Raditya Dika merupakan Youtuber yang memiliki spesialisasi dibidang komedi, dan konsisten mengunggah video-video bergaya komedi.

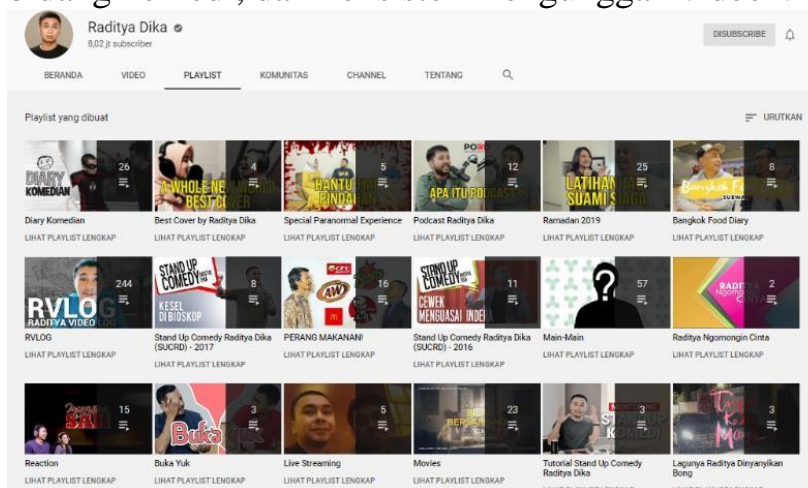

Gambar 5. Video-video yang Terdapat pada Channel Raditya Dika seluruhnya bergaya Komedi Source: youtube.com/user/radityadika [diakses, 2 Oktober 2019] 


\section{Authority (Otoritas)}

Otoritas yaitu dimana seseorang terlihat sebagai seorang ahli yang dikenal dalam bidang tertentu, dengan bakat yang luar biasa, sangat berpengalaman, dan dipandang sebagai seorang pemimpin yang efektif.

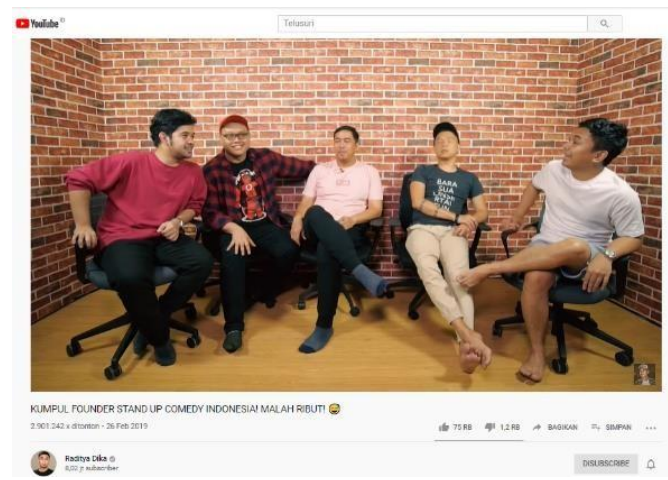

Gambar 6. Video Raditya Dika bersama Founder dari Stand up Comedy Indonesia

Source: youtube.com/user/radityadika [diakses, 2 Oktober 2019]

\section{Distinctiveness (Unik)}

Unik yaitu berbeda, atau memiliki ciri khas yang tidak dimiliki orang lain, sehingga memiliki nilai tambah terhadap brand diri. Raditya Dika jika dilihat pada pendapat subcribers account Youtube miliknya, dipandang sebagai Youtuber yang memiliki keunikan. Hal ini terlihat dari web series, yaitu Malam Minggu Niko. Komedian atau penulis komedi di Indonesia lainnya seperti Ernest Prakarsa maupun Pandji Pragiwaksono tidak memiliki web series di channel YouTube pribadinya. Hal tersebut yang menjadikan Raditya unik dari YouTubers lainnya.

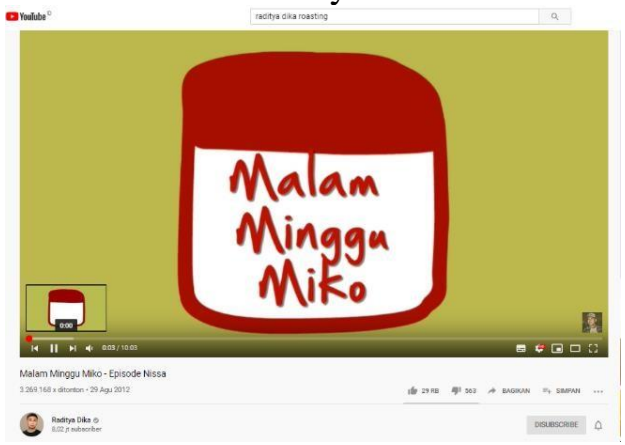

Gambar 7. Malam Minggu Miko merupakan web series yang Terdapat pada YouTube

Channel Raditya Dika.

Source: youtube.com/user/radityadika [diakses, 2 Oktober 2019]

7. Relevant (Relevan)

Relevan mengindikasikan bahwa seseorang harus terkait dengan sesuatu yang dianggap penting oleh audien. Raditya Dika sebagai seorang YouTubers dengan gaya komedi, terkait dengan berbagai hal yang berbau komedi, dimulai dari sutradara dan pemain film dengan genre komedi, memiliki tour stand up comedy, dan juga menjadi juri dalam ajang kompetensi stand up comedy. Maka apa yang dilakukan Raditya Dika dalam account Youtube miliknya, menjadikan nama Raditya Dika penting dalam dunia komedi Indonesia. Hal ini terbukti dari didapuknya Raditya Dika menjadi juri dalam ajang kompetensi stand up comedy.

\section{Visibility (Visibilitas)}

Visibilitas merupakan pengulangan terus-menerus dan pemaparan jangka panjang. Sejak mengupload video YouTubenya pada tahun 2012, Raditya Dika secara terus menerus memasukkan nilai komedi dalam setiap videonya.

\section{Persistence (Persistensi)}

Visibilitas dan persistensi memiliki tujuan sama, agar personal branding dari seseorang tertanam dibenak targetnya dalam jangka Panjang, sehingga melalui komedi Raditya Dika berhasil 
menanamkan personal branding sebagai seorang comedian. Hal ini terlihat dari Raditya Dika secara terus menerus konsisten mengunggah video-vide dengan gaya komedi

\section{Goodwill}

Goodwill adalah ketika seseorang sudah diasosiasikan secara positif oleh orang lain. Hasil wawancara dengan para subcribers Raditya Dika menunjukkan bahwa Raditya Dika bagi subcribers adalah salah satu YouTubers dengan konten-konten positif. Komedi yang dibawakan Raditya Dika tidak pernah viral secara negatif, maupun menyinggung individu atau golongan lain. Hal ini menjadikan citra Raditya Dika positif dimata para subcribersnya, terlihat dari banyaknya jumlah viewers paling banyak, yaitu 29 juta viewers, dengan jumlah like 594 ribu, dan jumlah dislike 18 ribu.

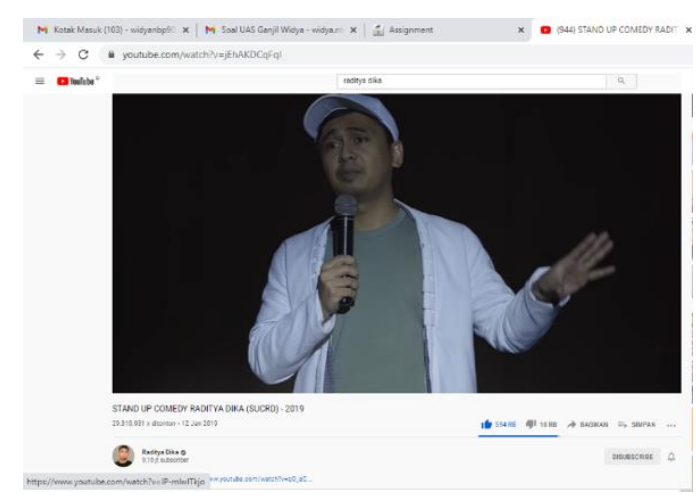

Gambar 8. Video Raditya Dika dengan Jumlah viewers Terbanyak Source: youtube.com/user/radityadika [diakses, 2 Oktober 2019]

\section{Performance (Kinerja)}

Kinerja, merupakan elemen penting setelah brand tersebut atau seseorang tersebut telah dikenal. Hal tersebut menggambarkan bagaimana kinerja seseorang, setelah menjadi terkenal. Raditya Dika saat ini tidak hanya dikenal sebagai pelaku komedi, namun juga sudah dijadikan dewan juri dibeberapa ajang kompetisi stand up comedy.

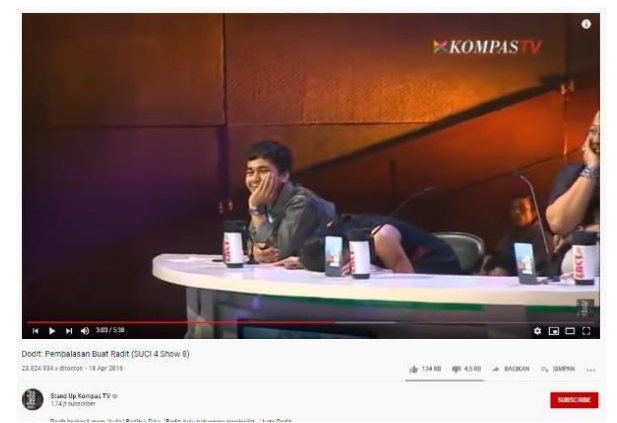

Gambar 9. Raditya Dika menjadi Salah Satu Juri Stand Up Comedy di Kompas TV Source: youtube.com/user/Standupkompastv [diakses, 2 Oktober 2019]

\section{SIMPULAN}

Raditya Dika dalam membangun personal branding melalui channel YouTubenya sejak tahun 2012, telah berhasil memenuhi kriteria authentic (keaslian), integrity (integritas), consistency (konsisten), specialization (spesialisasi), authority (otoritas), distinctiveness (unik), relevant (relevan), visibility (visibilitas), persistence (persistensi), goodwill, performance (kinerja). Berdasarkan kepada kriteria tersebut, personal branding yang paling dominan dari Raditya Dika adalah consistency dan specialization Raditya Dika dalam dunia komedi. 


\section{Saran}

Untuk penelitian selanjutnya, penulis berharap dapat digali lebih jauh mengenai faktor-faktor yang membuat seseorang sukses membangun personal branding, dan juga analisa hal-hal apa saja yang dapat dipengaruhi oleh personal branding.

\section{DAFTAR PUSTAKA}

[1] Abugaza, A. (2013). Social Media Politica. Jakarta: Tall Writing \& Publishing House.

[2] Agustinna, K. P., H, Abdurrahman, M.S., (2017). Analisis Strategi Personal Branding Melalui Media Sosial Instagram. E-proceeding of Management. Vol.4. (1028-1036)

[3] Bungin, B. (2008). Penelitian Kualitatif. Jakarta: Kencana Preneda Media Group.

[4] Franzia, E., (2018). Personal Branding melalui Media Sosial. E-proceesing Seminar Nasional Pakar ke 1.

[5] Haroen, D. (2014). Personal Branding: Kunci Kesuksesan Berkiprah di Dunia Politik. Jakarta: Gramedia.

[6] Kriyantono, R. (2006). Teknik Praktis Riset Komunikasi. Jakarta: Kencana

[7] Rakhmat, J.(2009). Metode Penelitian Komunikasi. Bandung: PT.Remaja Rosdakarya.

[8] Rangkuti, F. (2006). The Power of Brands: Teknik Mengelolan Brand Equity dan Strategi Pengembangan Merek dan Anlisis Kasus dengan SPSS. Jakarta: Gramedia.

[9] Septriadi, D. (2012). Analisis Proses Pembentukan Personal Branding melalui Social Media. Tesis Fakultas Ilmu Sosial dan Politik UI.

[10] Rampershad, H., K. (2008). Authentic Personal Branding. Jakarta: PPM.

[11] Soraya, I. (2017). Personal Branding Laudya Cynthia Bella Melalui Instagram. Jurnal Komunikasi. Vol 2. (2579-3292)

[12] Yunitasari, C., \& Japarianto, E., (2013). Analisis Faktor-faktor Pembentuk Personal Branding dari C.Y.N. Jurnal Manajemen Pemasaran Petra. Vol 1. (1 - 8). 